\title{
Kuliah dan Diskusi Online untuk Komunitas dengan Youtube Analytics
}

\author{
Ihan Martoyo ${ }^{1,2}$ \\ ${ }^{1}$ Teknik Elektro, Universitas Pelita Harapan \\ ${ }^{2}$ Sekolah Tinggi Teologi Reformed Indonesia (STTRI) \\ ihan.martoyo@uph.edu
}

\begin{abstract}
Abstrak
Pandemi Covid-19 memaksa seluruh perkuliahan di Indonesia untuk beralih kepada modus online. Di satu sisi, materi informasi akademis yang muncul di kanal terbuka seperti Youtube menjadi berlipatganda. Di lain pihak, perlu dilakukan analisis tentang minat komunitas terhadap materi ajar lewat kanal online seperti Youtube dan dampaknya. Untuk meneliti hal tersebut, sekaligus menyediakan materi ajar dan akademis online kepada masyarakat, sejak Maret 2020 sebuah kanal Youtube dipakai untuk memuat berbagai kandungan materi akademis demi layanan komunitas. Materi tersebut mencakup bidang teknik elektro, diskusi filsafat, diskusi teologi dan topik khusus lainnya, seperti online learning. Format materi bervariasi dari format sekitar $5-10$ menit, format diskusi sekitar 20-30 menit, dan format kuliah panjang sekitar 1 jam. Dengan analisis lewat data di Youtube Analytics dapat disimpulkan bahwa materi dengan durasi pendek di bawah 10 menit dan format diskusi 20-30 menit lebih diminati daripada kuliah panjang. Topik yang lebih menyentuh minat yang luas seperti filsafat atau teologi mendapatkan jumlah pemirsa yang lebih banyak dibandingkan topik sempit seperti teknik, ekonomi dan media. Pada bulan September 2020, kanal Youtube telah mempunyai 124 cuplikan video dan mendapatkan sekitar 100 views/hari. Dari bulan Maret-September 2020, telah terjadi penambahan 196 subscriber, yaitu 70\% dari total 280 subscriber yang ada.
\end{abstract}

Kata Kunci : kuliah online, youtube analytics, pandemi

\section{PENDAHULUAN}

Pandemi Covid-19 menuntut suatu pergeseran paradigma pembelajaran baru ke arah edukasi online. Penyediaan materi audio visual melalui kanal terbuka seperti Youtube merupakan sebagian kecil dari proses perkuliahan online yang dapat mencakup interaksi melalui Learning Management System (LMS) ataupun tatap-muka sinkron melalui video conferencing tools seperti Zoom, atau MS-Teams.

Untuk menyediakan materi ajar/akademis yang dipergunakan dalam perkuliahan, sekaligus membukanya untuk komunitas dan masyarakat luas, sejak pertengahan Maret 2020, dimulai penyediaan berbagai materi diskusi akademis melalui kanal Youtube yang terbuka untuk komunitas dan masyarakat (Martoyo, 2020). Sampai September 2020, kanal tersebut telah berisi 124 cuplikan video. Dalam paper ini akan disajikan analisis pergerakan data dari Youtube Analytics untuk menghasilkan kesimpulan tentang minat komunitas terhadap jenis maupun format materi yang tersedia lewat kanal Youtube tersebut. Pemahaman lebih mendalam tentang minat komunitas terhadap jenis dan format materi video akademis dapat mendorong teknik penyajian informasi yang lebih mudah diterima dan disukai masyarakat. 

MOOC $\begin{gathered}\text { Pengamatan terhadap materi video dalam } \\ \text { (Massive Open Online Course) }\end{gathered}$ menunjukkan bahwa video durasi pendek $(0-3$ menit) lebih digemari, video dengan talking head (lebih personal) lebih digemari daripada yang hanya slides, video yang bersifat tutorial lebih banyak dilihat daripada yang konseptual, dan video dengan tutor yang berbicara cepat dan antusias lebih banyak menuai engagement (Diwanji et al., 2014, Nov). Tackett et al. (2018) menemukan bahwa video kesehatan dengan topik hepatitis, epilepsy, gagal jantung dan diabetes menjadi bagian top-10 untuk semua lapisan ekonomi. Sedangkan topik seperti problem psikiatri, depresi dan anxiety lebih populer di kalangan ekonomi atas dibanding ekonomi menengah ke bawah. Jadi bukan hanya sifat materi video yang berpengaruh kepada jumlah views dan engagement, melainkan juga karakter dari komunitas darat pemirsa terkait.

Namun penyebab video menjadi viral mungkin lebih kompleks dan dapat mencakup faktor "opinion leaders", sifat video yang berisi humor, kelucuan dan menghibur (Elliott, 2013; Bauckhage, Hadiji \& Kersting, 2015, May), serta komentar-komentar yang datang dari Amerika (Xu, Park \& Park, 2017). Pentingnya "opinion leader" atau "fan base" yang akan mempengaruhi interaksi di media sosial juga dikonfirmasi banyak penelitian (Khan \& Vong, 2014; Mohr, 2014). Burgess \& Green (2018) mengklaim bahwa literasi media pada zaman ini haruslah termasuk mempunyai pengertian tentang kelakuan suatu platform seperti Youtube, yang tumbuh dalam budaya partisipasi publik.

\section{METODE}

Penyediaan materi akademis untuk komunitas dan masyarakat dilakukan melalui kanal publik Youtube yang dapat diakses secara terbuka dengan waktu pengamatan sekitar 6 bulan, antara pertengahan Maret 2020 sampai akhir September 2020 .

Materi yang disediakan di kanal Youtube tersebut mencakup pembahasan materi di bidang: (1) Teknik Elektro, (2) Filsafat, (3) Teologi, (4) Topik khusus, seperti: ekonomi, media, dan edukasi online. Format materi yang diunggah terdiri dari variasi utama berikut: (1) Materi pembahasan kuliah sekitar 1 jam, (2) Rekaman penjelasan pendek sekitar 5-10 menit, (3) Diskusi akademis tentang topik tertentu antara 20-30 menit dengan beberapa nara sumber.

Materi rekaman pendek dikerjakan dengan peralatan screen capture sederhana seperti Bandicam atau Active Presenter, sedangkan materi diskusi akademis dan pemaparan kuliah kebanyakan dilakukan dengan rekaman pertemuan lewat Zoom.

Karena kanal ini murni untuk akses bebas bagi komunitas/masyarakat, maka dihindari kebiasaan untuk meminta pemirsa secara eksplisit melakukan subscription ke kanal, seperti yang layaknya dilakukan para influencerlyoutuber. Dengan menghindari kebiasaan permintaan subscription tersebut, dapat diamati berapa laju peningkatan jumlah subscriber yang secara alami merasakan manfaat dari materi yang tersedia dan memutuskan untuk melakukan subscription.

Untuk melakukan analisis terhadap manfaat yang dirasakan komunitas dapat dilakukan dengan melihat data Youtube analytics, yang mencakup: jumlah views, watch time, subscribers, dan waktu unggah. Selain itu, berbagai jenis/format materi video juga dapat diperbandingkan, sehingga dapat diperoleh pemahaman lebih mendalam tentang cara menyajikan informasi yang lebih mudah diterima dan disukai oleh komunitas.

\section{HASIL DAN PEMBAHASAN}

\section{Youtube Analytics September 2020}

Tabel 1. Data Youtube Analytics Sept 2020

\begin{tabular}{|cccc}
\hline Judul Singkat & Tanggal & $\begin{array}{c}\text { Avg views } \\
\text { duration }\end{array}$ & Views \\
\hline Hitler & 10Jun2020 & $0: 47 / 1,1 \%$ & 429 \\
\hline Pengkhotbah (P1) & 2Sep2020 & $9: 47 / 26,7 \%$ & 295 \\
\hline Qohelet (P2) & 2Sep2020 & $6: 31 / 24,6 \%$ & 167 \\
\hline $\begin{array}{c}\text { Memahami } \\
\text { Konvolusi }\end{array}$ & 16Oct2018 & $1: 58 / 21,3 \%$ & 151 \\
\hline Apa itu Konvolusi & 16Oct2018 & $1: 54 / 35,6 \%$ & 151 \\
\hline Bohong putih & 21Sept2020 & $6: 11 / 15,9 \%$ & 111 \\
\hline Freud (P1) & 28Aug2020 & $2: 09 / 8,7 \%$ & 96 \\
\hline Pemikiran Cak Nur & 17Jul2020 & $13: 56 / 21,9 \%$ & 91 \\
\hline Anchor TV (P2) & 19Sep2020 & $3: 56 / 16,8 \%$ & 87 \\
\hline Disrupsi Media (P1) & 19Sep2020 & $5: 12 / 17,5 \%$ & 78 \\
\hline
\end{tabular}

Salah satu hasil data analytics standar yang disediakan youtube adalah data 28 hari terakhir (4 minggu terakhir). Namun Youtube juga dapat menyediakan data analytics per bulan tertentu, bahkan custom dalam rentang waktu tertentu. Data

$$
\text { Pendidikan }
$$


untuk bulan September 2020 dari kanal Youtube yang diamati menunjukkan 10 video dengan jumlah views terbanyak tampak pada Tabel 1 .

Dua hal terpenting yang menghasilkan views pada video Youtube adalah gambar thumbnail dan judul video (Veritasium, 2019, May). Berikut ini adalah judul lengkap dari video pada Tabel 1:

1. Hitler: Pemimpin Karismatik \& Hati Nurani Nazi - Junita, Kuliah Kepemimpinan, Teknik Elektro, UPH

2. Memahami Konvolusi (Kontinu) - Kuliah Sinyal dan Sistem, Teknik Elektro UPH

3. Apa itu Konvolusi + Contoh Soal - Kuliah Sinyal Sistem, Teknik Elektro UPH

4. Apakah bohong putih boleh (diskusi teori etika)? (P1) David Tobing M.Hum., Simeon Theojaya M.Th.

5. Pengkhotbah berlawanan dgn Amsal?(P1) Inawaty Teddy MTh, Pdt.Dr. Agus Santoso, Pdt. Yohanes Halim

6. Bagaimana menjadi anchor yang baik? Frida Lidwina, Dr. Beni Simangunsong

7. Diskusi Pemikiran Cak Nur - Sweet Talk Cafe' UPH, Dr. Franky Budi Hardiman (recorded 2019)

8. Bagaimana media TV menghadapi disrupsi teknologi? (P1) Frida Lidwina, Dr. Beni Simangunsong

9. Betulkah Qoheleth bernuansa apokaliptik?(P2) Pdt.Dr. Agus Santoso, Inawaty Teddy, Pdt. Yohanes Halim

10. Bagaimana cara Augustine membaca Alkitab? (P1) Pdt. Dr. Yohanes Budhi, Dr. Okky Chandra

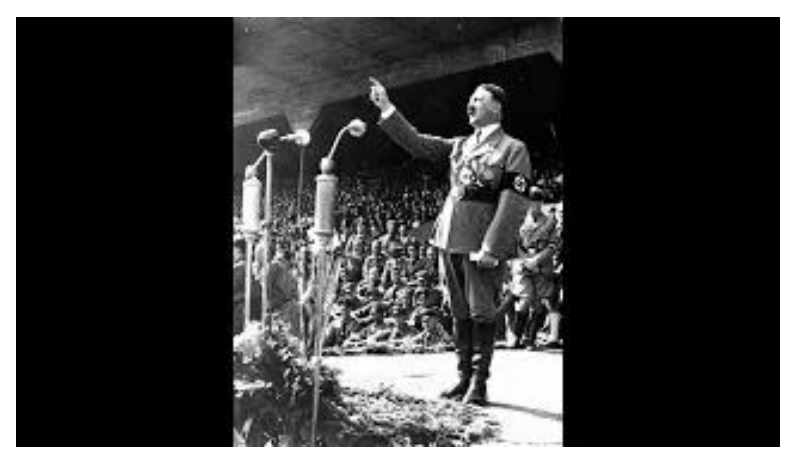

Gambar 1. Thumbnail video Hitler sedang berpidato

Dari Tabel 1, video yang paling tua adalah video Hitler, mendapatkan views yang paling banyak selama bulan September 2020, namun durasi rata-rata yang paling pendek. Video Hitler ini mengkonfirmasi bahwa pemilihan thumbnail (Gambar 1) dan judul merupakan faktor penting penarik untuk views. Ekspektasi terhadap judul dan gambar video yang cukup tinggi, dan isinya yang cenderung cukup teknis akademis (dapat membosankan), menyebabkan durasi views yang sangat rendah dari video pemaparan kuliah berdurasi 1 jam 13 menit ini. Apalagi Ibu Junita membahas buku Claudia Koonz (2003) tentang Hitler tanpa menyalakan kameranya pada video tersebut.

Video mengenai "konvolusi" yang sebenarnya dibuat oleh kelompok mahasiswa sebagai bagian tugas kuliah Sinyal dan Sistem menarik cukup banyak peminat. Walaupun sudah cukup lama diunggah (2018, Oct), kedua video pendek berdurasi di bawah 10 menit itu mendapatkan views cukup tinggi dibanding video lainnya pada Tabel 1. Hal ini mengkonfirmasi bahwa video berdurasi pendek, walaupun cukup teknis, bisa cukup diminati. Penulis menduga, terdapat banyak mahasiswa teknik elektro di seluruh Indonesia yang kesulitan memahami konsep konvolusi dan membutuhkan video penjelasan berbahasa Indonesia yang langka di Youtube, sehingga views terhadap kedua video tersebut cukup tinggi.

Video "Pengkhotbah", "Qoheleth" dan "Bohong Putih" pada Tabel 1 menunjukkan minat yang cukup besar dari komunitas terhadap diskusi teologi maupun teori etika. Selain itu, ketiga video dengan format diskusi 20 - 30 menit ini juga cukup baru, sehingga masih menuai banyak views yang baru. Tampaknya video dengan durasi sangat pendek (< 10 menit) dan diskusi durasi menengah (20 - 30 menit) termasuk yang cukup diminati dalam komunitas.

Video no 7 tentang pemikiran "Cak Nur" adalah rekaman video diskusi panjang (1 jam 3 menit) yang tampaknya cukup populer karena relevansi topik, kompetensi pembicara, dan editing profesional dari unit online education UPH. Gambar thumbnail yang merupakan hasil dari kerja editing profesional oleh unit online education UPH tampaknya juga sangat menentukan, seperti terlihat pada Gambar 2. 


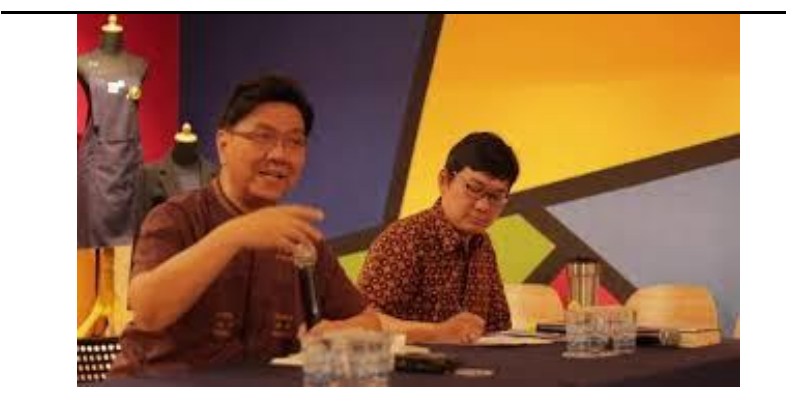

Gambar 2. Thumbnail video "Pemikiran Cak Nur"

\section{Youtube Analytics 365 hari}

Youtube analytics juga menyediakan data standar 365 hari terakhir, yang menyediakan perspektif yang lebih jangka panjang terhadap pergerakan data. Sepuluh video dengan views terbanyak selama 365 hari terakhir ditunjukkan di Tabel 2. Terlihat bahwa video pendek tentang "konvolusi" menduduki urutan pertama dan kedua dengan lebih dari seribu views. Video "Elektro-Mau Jadi Apa" (2012, Feb) dan "Beasiswa Fulbright" (2012, Aug) adalah juga video pendek dengan durasi < 10 menit dan berisi informasi seputar kuliah di Teknik Elektro UPH, dan pengalaman melamar serta mendapatkan beasiswa Fulbright. Jadi empat dari sepuluh video yang paling banyak dilihat selama 365 hari terakhir adalah video pendek berdurasi $<10$ menit.

Tabel 2. Data Youtube Analytics 365 hari

\begin{tabular}{|cccc}
\hline Judul Singkat & Tanggal & $\begin{array}{c}\text { Avg views } \\
\text { duration }\end{array}$ & Views \\
\hline $\begin{array}{c}\text { Apa itu Konvolusi } \\
\text { Memahami } \\
\text { Konvolusi }\end{array}$ & 16Oct2018 & $1: 48 / 34,0 \%$ & 1.237 \\
\hline $\begin{array}{c}\text { Elektro-Mau Jadi } \\
\text { Apa }\end{array}$ & 27Feb2012 & $2: 21 / 31,4 \%$ & 1.032 \\
\hline Hitler & 10Jun2020 & $0: 51 / 1,2 \%$ & 793 \\
\hline $\begin{array}{c}\text { Beasiswa Fulbright } \\
\text { Gereja Setelah } \\
\text { Pandemi (P1) }\end{array}$ & 6Aug2012 & $1: 06 / 38,5 \%$ & 676 \\
\hline $\begin{array}{c}\text { Pemikiran Karl } \\
\text { Marx (P1) }\end{array}$ & 17Jul2020 & $7: 18 / 28,9 \%$ & 435 \\
\hline $\begin{array}{c}\text { Mengapa Marx } \\
\text { Filsuf (P2) }\end{array}$ & 17Jul2020 & $4: 44 / 35,5 \%$ & 358 \\
\hline $\begin{array}{c}\text { Pemikiran Cak Nur } \\
\text { Khotbah Biblical } \\
\text { (P1) }\end{array}$ & 17Jul2020 & $13: 14 / 20,8 \%$ & 340 \\
\hline
\end{tabular}

Hanya dua dari sepuluh video dengan views paling banyak dalam 365 hari adalah video panjang berdurasi sekitar 1 jam, yaitu: video "Hitler" dan "Pemikiran Cak Nur." Video lainnya dalam Tabel 2 merupakan video diskusi 20 - 30 menit tentang topik khusus: Gereja setelah pandemic (P1), Pemikiran Karl Marx (P1), Mengapa Marx Filsuf (P2), dan Khotbah Biblical (P1).

\section{DISKUSI DAN ANALISIS}

Data dari Youtube analytics menunjukkan bahwa video berdurasi pendek $(<10$ menit) lebih menarik minat komunitas, walaupun cukup spesifik tentang aspek teknis/bidang tertentu. Di lain pihak, video berdurasi panjang sekitar 1 jam, harus mempunyai gambar thumbnail dan judul yang menarik, atau kualitas editing profesional untuk menarik minat komunitas. Sebagai pembanding untuk video "Pemikiran Cak Nur", video lain yang diedit oleh tim online education UPH secara profesional tentang pemikiran Immanuel Kant (12May2020, durasi 12 menit) sudah mendapatkan views lebih dari 2000 (EduTech UPH, 2020, May). Kualitas editing profesional, judul yang relevan dan durasi yang pas adalah faktor penentu cukup penting untuk meningkatkan minat komunitas terhadap video yang diunggah.

Kuliah-kuliah panjang yang cukup teknis berdurasi 1 jam memang biasanya tidak diteruskan lewat grup sosial media komunitas, melainkan hanya ditempelkan di LMS (Moodle) untuk diakses mahasiswa pada kelas tertentu, sehingga mendapatkan penambahan views, yang lebih lambat dibandingkan video diskusi 20-30 menit yang kebanyakan diteruskan lewat grup Whatsapp komunitas.

Berbagai video diskusi topik khusus dengan durasi 20 - 30 menit juga menunjukkan variasi minat komunitas, seperti terlihat dalam cuplikan data pada Tabel 3. Tampak dari Tabel 3 bahwa topik mengenai gereja, filsafat atau teologi mendapatkan minat yang lebih besar daripada topik khusus yang lebih sempit seperti "kuliah online". 
Tabel 3. Data Youtube Analytics untuk berbagai diskusi durasi 20-30 menit (data 365 hari)

\begin{tabular}{|cccc}
\hline Judul Singkat & Tanggal & $\begin{array}{c}\text { Avg views } \\
\text { duration }\end{array}$ & Views \\
\hline $\begin{array}{c}\text { Gereja Setelah } \\
\text { Pandemi (P1) }\end{array}$ & 29May2020 & $8: 02 / 27,9 \%$ & 490 \\
\hline $\begin{array}{c}\text { Pemikiran Karl } \\
\text { Marx (P1) }\end{array}$ & 17Jul2020 & $7: 18 / 28,9 \%$ & 435 \\
\hline $\begin{array}{c}\text { Khotbah Biblical } \\
\text { (P1) }\end{array}$ & 25Jun2020 & $5: 59 / 26,9 \%$ & 333 \\
\hline $\begin{array}{ccc}\text { Pengkhotbah (P1) } \\
\text { Feuerbach (P1) }\end{array}$ & 2Sep2020 & $10: 02 / 27,4 \%$ & 302 \\
\hline $\begin{array}{c}\text { Freud (P1) } \\
\text { Seberapa Susah }\end{array}$ & 28Aug2020 & $6: 31 / 29,9 \%$ & 277 \\
\hline $\begin{array}{c}\text { Mengajar Online } \\
\text { Khotbah yang }\end{array}$ & 9Jul2020 & $5: 19 / 15,9 \%$ & 266 \\
\hline $\begin{array}{c}\text { disukai pendeta (P2) } \\
\text { Kierkegaard (P1) }\end{array}$ & 21Aug2020 & $4: 52 / 24,3 \%$ & 210 \\
\hline $\begin{array}{c}\text { Tantangan Kuliah } \\
\text { Online }\end{array}$ & 8May2020 & $4: 17 / 11,9 \%$ & 160 \\
\hline
\end{tabular}

Tabel 4 menunjukkan berbagai diskusi yang lebih teknis dengan format 20 - 30 menit. Topiktopik pada Tabel 4 tampaknya mendapatkan views yang cenderung lebih rendah dibandingkan topik pada Tabel 3. Jadi topik diskusi yang umum dan lebih dapat dinikmati lapisan masyarakat yang lebih luas (Tabel 3) akan cenderung mendapatkan views yang lebih tinggi, termasuk topik teologi dan filsafat yang dirasa lebih relevan oleh kalangan yang lebih luas dibandingkan topik teknik, ekonomi atau media. Namun demikian, data perlu terus dicermati, karena video pada Tabel 4 memang lebih baru dibandingkan banyak video pada Tabel 3 .

Tabel 4. Data Youtube Analytics untuk berbagai diskusi teknis durasi 20-30 menit (data 365 hari)

\begin{tabular}{|cccc}
\hline Judul Singkat & Tanggal & $\begin{array}{c}\text { Avg views } \\
\text { duration }\end{array}$ & Views \\
\hline Sistem 5G (P1) & 7Aug2020 & $5: 48 / 23 \%$ & 115 \\
\hline Anchor TV (P2) & 19Sep2020 & $3: 58 / 16,9 \%$ & 96 \\
\hline $\begin{array}{c}\text { Iman \& ekonomi } \\
\text { pandemi (P1) }\end{array}$ & 24Jul2020 & $8: 06 / 31,1 \%$ & 93 \\
\hline $\begin{array}{c}\text { Disrupsi Media (P1) } \\
\text { Augustine (P1) }\end{array}$ & 19Sep2020 & $5: 27 / 18,4 \%$ & 87 \\
\hline $\begin{array}{c}\text { Kopi \& Prosesnya } \\
\text { (P1) }\end{array}$ & 1Oct2020 & $6: 02 / 19,6 \%$ & 79 \\
\hline $\begin{array}{c}\text { Menghemat Listrik } \\
\text { (P1) }\end{array}$ & 4Sep2020 & $7: 05 / 23,3 \%$ & 70 \\
\hline
\end{tabular}

Dalam setiap diskusi juga tampaknya videovideo Part 1 (P1) yang mendekati topik diskusi dari sudut yang lebih umum, cenderung mendapatkan views lebih tinggi dibandingkan video-video $\mathrm{P} 2$ atau P3 yang menyasar kepada aspek diskusi yang lebih spesifik dan sempit. Perkecualian yang muncul adalah pada topik "Khotbah yang disukai pendeta" (Tabel 3) dan "Anchor TV" (Tabel 4), di mana nara sumber mendiskusikan berbagai hal yang lebih personal. Jadi personalisasi dan topik yang lebih umum akan menghasilkan video yang lebih diminati public.

Dalam eksperimentasi selama kurang lebih 6 bulan ini (Maret - September), statistik umum dari Youtube analytics baru menunjukkan peningkatan berarti mulai bulan Mei, seperti yang tampak pada Tabel 5. Pada bulan Mei, dimulai berbagai diskusi 20-30 menit tentang berbagai topik yang akhirnya memicu kenaikan data statistik ketika video diskusi mulai diikuti dan dinikmati komunitas.

Tabel 5. Views, Time \& Subscriber antara Maret September 2020

\begin{tabular}{cccc}
\hline Bulan 2020 & Views & $\begin{array}{c}\text { Watch Time } \\
\text { (Jam) }\end{array}$ & Subscriber \\
\hline Maret & 582 & 20,5 & +4 \\
\hline April & 733 & 25,6 & +6 \\
\hline Mei & $1,5 \mathrm{~K}$ & 153,3 & +29 \\
\hline Juni & $1,5 \mathrm{~K}$ & 127 & $+\_19$ \\
\hline Juli & $2,8 \mathrm{~K}$ & 250,6 & +57 \\
\hline Agustus & $2,3 \mathrm{~K}$ & 198,7 & +47 \\
\hline September & $3,1 \mathrm{~K}$ & 247,9 & +34 \\
\hline
\end{tabular}

Dari Tabel 5 juga tampak bahwa rata-rata views pada bulan Juli - September adalah sekitar 2,8K/bulan atau sekitar 100 views/hari. Sementara itu, selama bulan Maret - September terjadi penambahan 196 subscriber, yang merupakan 70\% dari total subscriber saat ini (280 subscriber).

Data penambahan jumlah subscriber juga merupakan informasi penting tentang minat komunitas terhadap video tertentu, yang membuatnya ingin terus mengikuti berbagai video dari kanal tersebut. Tabel 6 menunjukkan jumlah penambahan subscriber dan views untuk video-

$$
\text { Pendidikan }
$$


video yang populer. Tampak bahwa video yang mendapatkan top-10 views pada 365 hari terakhir (Tabel 2) cenderung menghasilkan penambahan subscriber yang juga tinggi.

Tabel 6. Data subscribers \& views total

\begin{tabular}{|cccc}
\hline Judul Singkat & Tanggal & Views & Subscriber \\
\hline $\begin{array}{c}\text { Elektro-Mau } \\
\text { Jadi Apa }\end{array}$ & 27Feb2012 & 28.745 & +45 \\
\hline $\begin{array}{c}\text { Pemikiran Karl } \\
\text { Marx (P1) }\end{array}$ & 17Jul2020 & 435 & +20 \\
\hline $\begin{array}{c}\text { Beasiswa } \\
\text { Fulbright }\end{array}$ & 6Aug2012 & 6.919 & +19 \\
\hline $\begin{array}{c}\text { Memahami } \\
\text { Konvolusi }\end{array}$ & 16Oct2018 & 1.681 & +10 \\
\hline $\begin{array}{c}\text { Khotbah yang } \\
\text { disukai pendeta } \\
\text { (P2) }\end{array}$ & 9Jul2020 & 219 & +10 \\
\hline Kierkegaard (P1) & 21Aug2020 & 210 & +9 \\
\hline $\begin{array}{c}\text { Gereja Setelah } \\
\text { Pandemi (P1) }\end{array}$ & 29May2020 & 490 & +9 \\
\hline $\begin{array}{c}\text { Khotbah Biblical } \\
\text { (P1) }\end{array}$ & 25Jun2020 & 333 & +8 \\
\hline
\end{tabular}

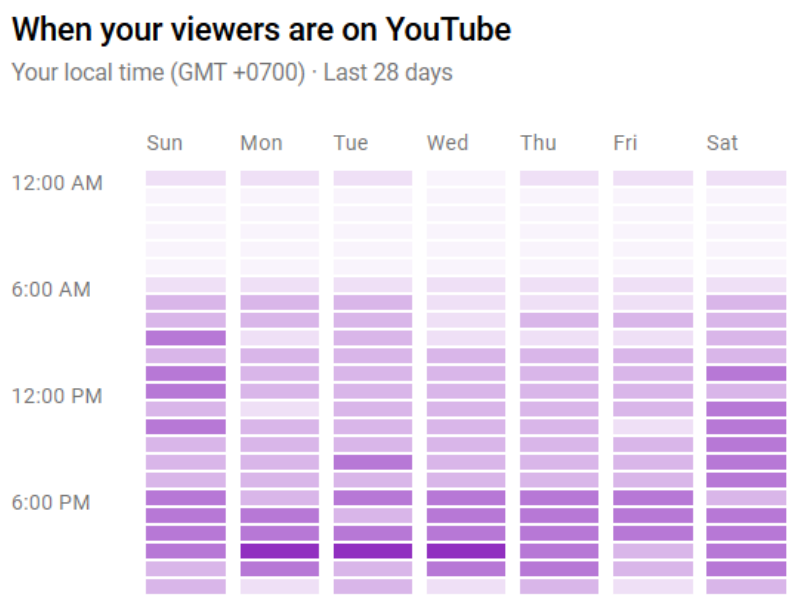

Gambar 3. Sebaran waktu akses video Youtube

Youtube analytics juga menyediakan sebaran waktu akses pemirsa video pada kanal Youtube tertentu seperti terlihat pada Gambar 3. Tampak bahwa akses pada hari Sabtu dan Minggu lebih tinggi (warna biru lebih gelap). Dan akses pada malam hari di hari kerja lebih tinggi, mulai sekitar jam 4 atau 5 sore, dan meningkat setelah jam 9 malam.

Data lain yang cukup menarik adalah sumber traffic yang diterima kanal. Dengan data 90 hari terakhir, kanal Youtube masih menerima views dari terbanyak dari sumber eksternal (grup WA dan FB) sebesar 33,5\% dan dari Youtube search 29,9\% dan browse features 10,9\%. Namun terjadi pergeseran persentase traffic jika melihat data bulan September saja, dari Youtube search meningkat menjadi $35,1 \%$ dan eksternal turun ke $26,1 \%$, sedangkan browse features meningkat ke 16,2\%.

Jadi terlihat bahwa secara jangka panjang, Youtube search dan browse features yang akan memberikan traffic yang stabil kepada kanal, bukan lagi forward lewat grup WA atau FB. Hal ini juga dikonfirmasi dalam penelitian yang mengamati bahwa search dan rekomendasi adalah dua komponen utama yang menghasilkan views secara jangka panjang (Zhou et al., 2016). Di samping itu, Welbourne \& Grant (2016) juga menemukan bahwa konten yang bukan berasal dari produksi profesional, tetap dapat menjadi cukup populer jika ada science communicator yang konsisten.

\section{KESIMPULAN}

Sebuah kanal terbuka Youtube dibentuk untuk menyalurkan materi video akademis sejak Maret - September 2020, yang mencakup video dengan format: (1) Video pendek dengan durasi < 10 menit, (2) Video diskusi topik tertentu dengan durasi 20 - 30 menit dengan beberapa nara sumber, dan (3) Video kuliah panjang (monolog) dengan durasi sekitar 1 jam. Analisis terhadap minat dan penerimaan komunitas/masyarakat terhadap 124 cuplikan video yang telah dihasilkan di kanal Youtube dilakukan dengan Youtube analytics.

Video pendek dengan durasi $<10$ menit dan diskusi 20 - 30 menit dengan beberapa nara sumber tampaknya lebih diminati daripada kuliah dengan durasi panjang sekitar 1 jam. Judul yang relevan dan gambar thumbnail yang menarik tampaknya merupakan faktor utama dalam memicu views. Hal ini terutama tampak dalam video "Hitler" yang secara jangka panjang menerima cukup banyak views, namun durasi tonton sangat rendah, karena berisi diskusi akademis dari sebuah buku sejarah Nazi Jerman. Kelakuan views yang tinggi dengan 
durasi tonton rendah menunjukkan pentingnya judul video dan gambar thumbnail untuk memicu views, yang tampaknya banyak dimanfaatkan oleh youtuber.

Dari analisis topik video diskusi $20-30$ menit, tampak bahwa topik yang lebih luas seperti filsafat dan teologi lebih diminati daripada topik yang lebih teknis dan sempit seperti teknik elektro, ekonomi atau media. Topik yang mendiskusikan hal-hal yang lebih personal seperti "khutbah yang disukai pendeta" atau "menjadi anchor TV yang baik" (Frida Lidwina) mendapatkan lebih banyak views daripada topik akademis yang kurang personal. Selain itu, editing yang profesional dapat juga membuat video diskusi yang cukup panjang dengan durasi sekitar 1 jam ("Pemikiran Cak Nur") cukup diminati.

Pada bulan September 2020, kanal menerima rata-rata 100 views/hari, dan penambahan lebih dari 30 subscriber/bulan. Selama bulan MaretSeptember 2020, kanal sudah menambah 196 subscriber, yaitu $70 \%$ dari total 280 subscriber saat artikel ini ditulis.

\section{REFERENSI}

Bauckhage, C., Hadiji, F., \& Kersting, K. (2015, May). How viral are viral videos?. In ICWSM (pp. 22-30).

Burgess, J., \& Green, J. (2018). YouTube: Online video and participatory culture. John Wiley $\&$ Sons.

Diwanji, P., Simon, B. P., Märki, M., Korkut, S., \& Dornberger, R. (2014, November). Success factors of online learning videos. In 2014 International Conference on Interactive Mobile Communication Technologies and Learning (IMCL2014) (pp. 125-132). IEEE.

EduTech UPH. (2020, May). Immanuel Kant: Betulkah Mendamaikan Empirisme dan Rasionalisme? (P1) - Dr. Fitzgerald Sitorus. Retrieved from: https://www.youtube.com/watch?v=K rLueNyWq $\underline{\mathrm{U} \& \mathrm{t}=7 \mathrm{~s}}$
Elliott, L. (2013). What makes a nonprofessional video go viral: a case study of "I'm farming and I grow it" (Doctoral dissertation, Kansas State University).

Khan, G. F., \& Vong, S. (2014). Virality over YouTube: an empirical analysis. Internet research.

Koonz, C. (2003). The nazi conscience (p. 15). Cambridge, MA: Belknap Press.

Martoyo, I. (2020). Youtube Channel: Ihan Martoyo - EE UPH - STTRI. Retrieved from: https://www.youtube.com/channel/UC3qezA1P6yO XibqUneXDQ4w

Mohr, I. (2014). Going viral: An analysis of YouTube videos. Journal of Marketing Development and Competitiveness, 8(3), 43.

Tackett, S., Slinn, K., Marshall, T., Gaglani, S., Waldman, V., \& Desai, R. (2018). Medical education videos for the world: an analysis of viewing patterns for a YouTube channel. Academic medicine, 93(8), 1150-1156.

Veritasium. (2019, May). My Video Went Viral. Here's Why. Retrieved from: https://www.youtube.com/watch? $v=f H$ sa9DqmId8

Welbourne, D. J., \& Grant, W. J. (2016). Science communication on YouTube: Factors that affect channel and video popularity. Public understanding of science, 25(6), 706-718.

Xu, W. W., Park, J. Y., \& Park, H. W. (2017). Longitudinal dynamics of the cultural diffusion of Kpop on YouTube. Quality \& Quantity, 51(4), 1859-1875.

Zhou, R., Khemmarat, S., Gao, L., Wan, J., \& Zhang, J. (2016). How YouTube videos are discovered and its impact on video views. Multimedia Tools and Applications, 75(10), 60356058. 